\title{
Analyses of heavy metals in attic dust of a former industrial city (Ózd, Hungary)
}

\author{
NELSON SALAZAR ${ }^{1}$, GORKHMAZ ABBASZADE ${ }^{2}$, \\ DAVAAKHUU TSERENDORJ ${ }^{2}$, PÉTER VÖLGYESI ${ }^{3}$, DÓRA \\ ZACHÁRY $^{4}$, KATALIN ZSUZSANNA SZABÓ ${ }^{3}$ AND \\ CSABA SZABÓ ${ }^{5}$
}

${ }^{1}$ Eötvös Loránd University, Institute of Geography and Earth Sciences

${ }^{2}$ Lithosphere Fluid Research Lab, Eötvös University

${ }^{3}$ Centre for Energy Research

${ }^{4}$ Research Centre for Astronomy and Earth Sciences

${ }^{5}$ Eötvös University

Presenting Author: salazaryaneznelson@gmail.com

Ózd is a former Hungarian industrial city exposed to air pollution for decades by several anthropogenic activities such as iron-steelwork, coal mine, transportation, which resulted in accumulation of heavy metals in attic areas and also incorporated into the house dust for several decades. To assess the quality of the urban environment, concentrations of 15 heavy metals (Ti, V, $\mathrm{Cr}, \mathrm{Mn}, \mathrm{Fe}, \mathrm{Co}, \mathrm{Ni} \mathrm{Cu}, \mathrm{Zn}, \mathrm{Mo}, \mathrm{Ag}, \mathrm{Sn}, \mathrm{Sb}, \mathrm{Pb}$ and $\mathrm{W})$ were measured in 43 attic dust samples collected from various houses, built at least 30 years ago.

This study uses compositional data analysis clr-transformed (clr-biplot), k-means cluster analysis (CA) and enrichment factors (EF) to observe the relationships among the selected elements. The results of k-means overlapped on the clr-biplot. Enrichment factors were calculated, by using $\mathrm{Fe}$ as a reference element, for every cluster. Background values were taken from a local brown forest soil sample.

Median values of heavy elements (in $\mathrm{mg} \mathrm{kg}^{-1}$ ) for studied attic dust samples are $\mathrm{Fe}(43600), \mathrm{Zn}(1351), \mathrm{Mn}(1218), \mathrm{Pb}$ (411), Ti (220), $\mathrm{Cu}(98), \mathrm{Cr}(56), \mathrm{V}(42), \mathrm{Ni}(27), \mathrm{Sn}(16), \mathrm{Sb}(8.9), \mathrm{Co}(6.9)$, $\mathrm{Mo}(4.5), \mathrm{W}(3.64)$ and $\mathrm{Ag}$ (1.108), respectively.

The optimal number of clusters is 4 , where the first cluster is in the south part of the city, close to coal mines. A few samples of the second cluster are distributed on the northwest side of the city near agricultural fields and the rest spread in urban areas like samples belonging to the third cluster. Samples forming the fourth cluster are around the former iron-steel factory area and cover the southern side of the city, next to former coal mines. The results of median enrichment factor $(E F)>5$, which represent significant or very significant enrichment, are $1^{\text {st }}$ cluster $\mathrm{Cu}>\mathrm{Sn}>\mathrm{Pb}>\mathrm{Zn}>\mathrm{Sb}>\mathrm{W}>\mathrm{Ti}, \quad 2^{\text {nd }}$ cluster $\mathrm{W}>\mathrm{Ti}>\mathrm{Sn}>\mathrm{Sb}>\mathrm{Ag}>\mathrm{Zn}>\mathrm{Pb}>\mathrm{Cu}>\mathrm{Mo}, \quad 3^{\text {rd }}$ cluster $\mathrm{W}>\mathrm{Ti}>\mathrm{Sn}>\mathrm{Sb}>\mathrm{Ag}>\mathrm{Pb}>\mathrm{Zn}>\mathrm{Cu}$, and $4^{\text {th }}$ cluster $\mathrm{Zn}>\mathrm{W}>\mathrm{Pb}>$ $\mathrm{Sn}>\mathrm{Ag}>\mathrm{Sb}>\mathrm{Ti}>\mathrm{Cu}$.

The differences among cluster patterns and enrichment factors of elements show a heterogeneous heavy metals distribution scenario, which suggests distinct areas in the city related to hybrid sources of the studied heavy elements.

Keywords: Urban environment, attic dust, assessment of heavy elements, enrichment factor, clr-biplot, k-means, urban area. 